Identity and Territory 



\section{Identity and Territory}

Jewish Perceptions of Space in Antiquity

\section{Eyal Ben-Eliyahu}

甲

UNIVERSITY OF CALIFORNIA PRESS 
University of California Press, one of the most distinguished university presses in the United States, enriches lives around the world by advancing scholarship in the humanities, social sciences, and natural sciences. Its activities are supported by the UC Press Foundation and by philanthropic contributions from individuals and institutions. For more information, visit www.ucpress.edu.

University of California Press

Oakland, California

(C) 2019 by The Regents of the University of California

\section{Library of Congress Cataloging-in-Publication Data}

Names: Ben-Eliyahu, Eyal, author.

Title: Identity and territory : Jewish perceptions of space in antiquity / Eyal Ben-Eliyahu.

Description: Oakland, California : University of California Press, [20I9] I Includes bibliographical references and index. I

Identifiers: LCCN 20I80384 I 6 (print) I LCCN 20I 8042482 (ebook) I ISBN 9780520966789 I ISBN 978052029360 I (cloth : alk. paper)

Subjects: LCSH: Space-Religious aspects-Judaism. I Jews-Identity-History-To I 500 . I JudaismHistory-Post-exilic period, 586 B.C.-2 IO A.D.

Classification: LCC вм729.S76 (ebook) I LCC BM729.s76 B46 20I9 (print) I DDC 296.3/82-dc23

LC record available at https://lccn.loc.gov/20I 80384 I 6

Manufactured in the United States of America

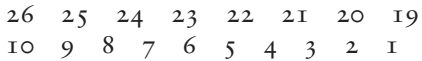


For Hila 
